\title{
Effect of fertigation of primary nutrients on pomegranate (Punica granatum L.) fruit productivity and quality
}

\author{
Nekha Tanari ${ }^{1}$, Suma Ramegowda ${ }^{2}$, Anusree $\operatorname{Thottan}^{1}$ and Manjunatha Girigowda $^{3}$ \\ ${ }^{1}$ Department of Soil Science and Agricultural Chemistry, College of Horticulture, \\ University of Horticultural Sciences, Bagalkot, Karnataka, India \\ ${ }^{2}$ Zonal Agricultural Research Station, V.C.Farm, Mandya, Karnataka, India \\ ${ }^{3}$ Regional Horticulture Research and Extension, Centre, GKVK, Bangalore, Karnataka, India
}

*Corresponding Author: sumassac@gmail.com

[Accepted: 19 November 2019]

\begin{abstract}
The present research work was conducted in 5year-old pomegranate orchard cultivating Bhagwa variety to evaluate the effect of fertigation and soil application of primary nutrient on its fruit yield and quality parameters. The experiment comprised of six treatments with four replications that included application of $100 \%$ recommended dose of fertilizer (RDF) through soil application (SA) (T1) and fertigation (F) (T6), supplementing 50\% (T2 and T3) and 75\% (T4 and T5) of RDF through fertigation following two different nutrient application schedules. In schedule1, nutrient application rate and time was retained closer to existing soil application recommendation i.e., percent $\mathrm{RD} \mathrm{N}: \mathrm{P}_{2} \mathrm{O}_{5}: \mathrm{K}_{2} \mathrm{O}$ at the rate of 20:20:20 as basal, 50:50:50 at active growth stage and 30:30:30 at rest period. But in schedule-2 nutrient rate at basal and rest application was reduced to 5:15:15 and 20:10:10 percent respectively and relatively higher nutrient rate $(75: 75: 75)$ was applied during active growth. The result indicated that $75 \%$ supplementation of nutrient through fertigation $\left(\mathrm{T}_{5}-25 \% \mathrm{SA}+75 \% \mathrm{~F}\right)$ following schedule-2 has produced highest fruit yield (18.49 kg plant ${ }^{-1}$ ), number of fruits per plant (67.25) and hermaphrodite flowers (128). The fruit quality parameters viz., fruit weight $(288.50 \mathrm{~g})$, fruit size, peel weight $(98.3 \mathrm{~g})$, aril to peel ration (1.87), aril weight (183.4 g) and aril size and juice quality parameter viz., titrable acidity, ascorbic acid, phenolic content and antioxidant activity in peel and juice was found highest in $100 \%$ fertigation $\left(\mathrm{T}_{6}\right)$. The mineral content of pomegranate juice was in the order of $\mathrm{K}>\mathrm{N}>\mathrm{P}>\mathrm{S}>\mathrm{Ca}>\mathrm{Mg}$ and seed was in the order of $\mathrm{N}>\mathrm{K}>\mathrm{P}>\mathrm{Ca}>\mathrm{S}>\mathrm{Mg}$ and was found in higher concentration in $\mathrm{T}_{6}(100 \% \mathrm{~F})$ than $\mathrm{T}_{1}(100 \% \mathrm{SA})$. The fertigation schedule- 2 was found superior in enhancing pomegranate fruit yield and quality as compared to schedule-1.
\end{abstract}

Keywords: Antioxidant activity - Aril to peel ratio - Ascorbic acid - Soil application.

[Cite as: Nekha T, Suma R, Anusree T \& Manjunatha G (2019) Effect of fertigation of primary nutrients on pomegranate (Punica granatum L.) fruit productivity and quality. Tropical Plant Research 6(3): 424-432]

\section{INTRODUCTION}

The sustainability of any production system requires optimum utilization of resources like water, fertilizer and soil. Fertigation is a modern agro technique that has the potential to combining water and fertilizer application through irrigation and provides an excellent opportunity to maximize yield and nutrient use efficiency besides, minimizing the crop requirement and environmental pollution (Li et al. 2002, Kafkafi \& Tarchitzky 2011). In semi-arid and arid climatic conditions optimum water supply depends on irrigation. Drip irrigation system has gained wide popularity in areas of acute water scarcity and in the areas where horticultural crops are grown. The water use efficiency is much higher in pressurized irrigation systems and coupling nutrient application in this drip irrigation system will have added advantage of improving nutrient management. Thus, fertigation technique coupled with drip system can economize the use of fertilizer.

Among the various factors responsible for increasing crop production, the use of balanced fertilizer at the right time, right quantity, source and method plays a vital role in enhancing productivity. Since pomegranate is high-value crop most of farmers are following drip irrigation method and are in need of proper fertigation 
schedule for enhancing crop productivity. Pomegranate (Punica granatum L.) is one of the important fruit crops of semi-arid region and extensively exported from India. To boost production, its management practices need to be refined of which mineral nutrition plays major role in determining yield and quality of the fruits. Under subtropical conditions, pomegranate bears heavily which can exhaust the essential elements in soil, needed for proper growth and development. A regular supply of these nutrients needs to be ensured for sustainable production. Balanced nutrition and proper irrigation scheduling are very essential for proper growth, development and maximum productivity of the plant.

The literature on fertigation of nutrients to pomegranate indicated it as an effective means of controlling the timing and placement of fertilizers to the root zone of the crop. This is known to improve the fertilizers use efficiency by reducing nutrient loss from leaching, volatilization and by fixation in the soil to less available forms. Firake \& Deolankar (2000) compared the effect of various levels (75, 100 and 125\% RD) of solid soluble fertilizers applied through a drip system on the yield and quality of pomegranate. They reported that highest yield, number of fruits per plant was obtained under the treatment comprising 100\% RD of fertilizers. However, fertigation with $75 \% \mathrm{RD}$ of NPK ( $625 \mathrm{~g} \mathrm{~N}, 250 \mathrm{~g} \mathrm{P}_{2} \mathrm{O}_{5}$ and $\mathrm{K}_{2} \mathrm{O} /$ plant) through fertilizer was as good as the $100 \%$ RD of conventional fertilizers. Idate et al. (2001) reported that application 75\% RD of fertilizers through fertigation recorded the maximum yield without impairing the quality of fruits, thus suggesting $25 \%$ fertilizers savings over conventional soil fertilization. Firake \& Kumbhar (2002) reported 30\% saving in the fertilizer dose and $36 \%$ increase in yield with application of $70 \%$ RD of NPK through fertigation technique as compared to $100 \%$ RD of NPK through conventional soil application.

Agarwal et al. (2004) indiacted application of $80 \%$ nutrienet application using water soluble fertilizers resulted in the economic yield of $52.5 \mathrm{q} \mathrm{ha}^{-1}$ with benefit-cost ratio of 3.21. Similarly, drip irrigation found beneficial in enhancing pomegranate groth parameter viz., tree height, stem diameter and canopy spread (Sulochanamma et al. 2005) besides, fruit yield and fruit weight (Prasad et al. 2003). Adequate soil moisture throughout the growing season is a key factor in pomegranate production, particularly as harvest approaches in late summer and early autumn, because it helps to reduce the number of split fruit (Larue 1980). It is especially important to avoid drought stress during initial fruit set (Still 2006). Singh et al. (2006) recording highest yield $\left(14.89 \mathrm{~kg} \mathrm{plant}^{-1}\right)$ for $100 \% \mathrm{RD}$ through fertigation however, $75 \% \mathrm{RD}$ through fertigation recorded highest number of fruit per plant, aril weight, fruit weight, fruit volume and rind thickness in pomegranate cv. Ganesh. Besides the nutrient quantity, the time of its application plays vital role in yield and quality of pomegranate. Rao \& Subramanyam (2009) reported highest plant height, stem girth with 50\% recommended dose of nitrogen at fortnight intervals followed by 50\% recommended dose of nitrogen at monthly intervals. Dhankar et al. (2010) observed that fertigation level at $100 \%$ recommended dose of fertilizers at alternate day showed significantly higher vegetative growth and physico-chemical characteristics.

Shanmugasundaram \& Balakrishnamurthy (2013) revealed that application of 50\% recommended dose of fertilizers through fertigation enhanced flower, fruit yield \& fruit quality parameters viz., fruit weight $(211.43 \mathrm{~g})$, fruit volume (228.75 cc), peel weight $(62.83 \mathrm{~g})$, total aril weight $(127.53 \mathrm{~g}), 100$ aril weight $(22.31 \mathrm{~g})$, total seed weight (14.87 g) and fruit yield (11.1 kg/ plant) as compared to soil application. Jhakar (2010) found significant effect of $100 \%$ recommended dose of fertilizers through fertigation on relative growth rate of shoots, plant spread and height in pomegranate. Haneef et al. (2014) recorded highest vegetative growth and yield contributing characteristics, yield and leaf N, P \& K contents along with minimum acidity, juice content, TSS and organoleptic score in pomegranate $\mathrm{cv}$. Bhagwa with $125 \%$ recommended dose of fertilizers. Whereas TSS: acid ratio was high at $100 \% \mathrm{RDF}$ through fertigation.

The existing nutrient recommendation for pomegranate are basically for soil application and vary considerably among different farm institutes (400-625:200-250:200-250 N: $\mathrm{P}_{2} \mathrm{O}_{5}: \mathrm{K}_{2} \mathrm{O}$ g plant $\left.{ }^{-1}\right)$ and from place to place (viz. 500-1000: 500: 250-500 - N: $\mathrm{P}_{2} \mathrm{O}_{5}: \mathrm{K}_{2} \mathrm{O}$ g plant ${ }^{-1}$ ) (Singh et al. 1988, Prasanna \& Dhander 1999). Further, the time of nutrient application has also known to have significant influence on pomegranate yield and quality viz., nitrogen on flowering pattern, potassium on fruit colour, calcium and boron on fruit cracking etc. (Gosh et al. 1996). Thus, there is need to study effective use of fertilizer nutrients with a goal to match nutrient supply with crop requirements and minimize nutrient losses from fields.

Fertigation technique allows uniform and exact measured amount of nutrient application to plant rhizosphere. However, this technique is associated with certain limitation viz., relatively higher initial and maintenance cost, water pressure for uniform distribution of nutrients to all plants in the fields, clogging of emitter, undulating field condition that restricts uniform water and nutrient application, power problem for running the system, lack of availability of expertise for effective use of the system, lack of fertigation schedule 
to supply the optimum nutrient etc. Hence, it is sometimes difficult to completely relay on fertigation for nutrient management. Combining various fertilizer application methods thus becomes important in optimizing nutrient schedule to meet crop requirement and farmers need. In this context the present study was formulated with the aim to study the quantity and time of primary nutrient application at various pomegranate growth stages through fertigation and soil application on its yield and quality

\section{MATERIAL AND METHODS}

\section{Field experiment}

A field experiment was carried out in a five-year-old pomegranate orchard at Udyanagiri, Navanagar, Bagalkot, India. The location comes under northern dry zone of Karnataka and situated at $16.16^{\circ} \mathrm{N}$ latitude and $75.65^{\circ}$ E longitude at an altitude of $678.00 \mathrm{~m}$ above Mean Sea Level (MSL). The plant spacing was $4.5 \times 4.5 \mathrm{~m}$ with a plant population of 493 plants $\mathrm{ha}^{-1}$. The experiment was laid out with six levels of NPK and replicated four times. The cropping season was Hasta bahar, where in pomegranate plants were put into artificial stress by withholding water for one month and leaves were defoliated during third week of August by spraying ethrel (2.0-2.5 ml litre ${ }^{-1}$ ). The plants were then pruned, lightly irrigated and applied with recommended dose of fertilizer. The new flushes appeared on the tree between 15-20 days and profuse flowering were observed during second fortnight of September. The observations were recorded at various stages uniformly for all the treatments.

\section{Treatment details}

The nutrient recommendation for pomegranate as given by University of Horticultural Sciences, Bagalkot i.e 400:200:200 N: $\mathrm{P}_{2} \mathrm{O}_{5}: \mathrm{K}_{2} \mathrm{O}$ gram plant ${ }^{-1}$ was followed to implement the experiment that comprise six treatments and four replication as described below,

$\begin{array}{ll}\mathrm{T}_{1}: & 100 \% \mathrm{SA} \\ \mathrm{T}_{2}: & 50 \% \mathrm{SA}+50 \% \mathrm{~F}(\text { Schedule-1) } \\ \mathrm{T}_{3}: & 50 \% \mathrm{SA}+50 \% \mathrm{~F} \text { (Schedule- }) \\ \mathrm{T}_{4}: & 25 \% \mathrm{SA}+75 \% \mathrm{~F} \text { (Schedule- }) \\ \mathrm{T}_{5}: & 25 \% \mathrm{SA}+75 \% \mathrm{~F} \text { (Schedule- }) \\ \mathrm{T}_{6}: & 100 \% \mathrm{~F}\end{array}$

The recommended dose of nutrients required for different treatments were applied using soluble fertilizers viz., mono ammonium phosphate (12-60-0), urea, sulphate of potash and phosphoric acid through fertigation and di-ammonium phosphate, urea and sulphate of potash for soil application. Two fertigation schedules were followed to fulfill the recommended dose of primary nutrients to pomegranate plants. In schedule- 1 nutrient application rate and time was retained closer to recommendation i.e., percent RD N: $\mathrm{P}_{2} \mathrm{O}_{5}: \mathrm{K}_{2} \mathrm{O}$ as 20:20:20 as basal, 50:50:50 at active growth stage and 30:30:30 at rest period. The basal and rest period nutrient application rate was reduced to 5:15:15 and 20:10:10 percent $\mathrm{RD} \mathrm{N}: \mathrm{P}_{2} \mathrm{O}_{5}: \mathrm{K}_{2} \mathrm{O}$ respectively in fertigation schedule-2 however, high nutrient rate (75:75:75\% RD N: $\left.\mathrm{P}_{2} \mathrm{O}_{5}: \mathrm{K}_{2} \mathrm{O}\right)$ was applied during active growth stage as following,

\begin{tabular}{lll} 
& \multicolumn{2}{l}{ Percent recommended dose of $\mathrm{N}: \mathrm{P}_{2} \mathrm{O}_{5}: \mathrm{K}_{2} \mathrm{O}$} \\
& Schedule-1 & Schedule-2 \\
Basal & $20: 20: 20$ & $5: 15: 15$ \\
Active growth stage & $50: 50: 50$ & $75: 75: 75$ \\
Rest period & $30: 30: 30$ & $20: 10: 10$
\end{tabular}

Fertigation was done through a pressure differential tank system. This system utilizes an pressure metal tank with anti-acid internal wall protection in which a pressure differential is created by a throttle valve that diverts part of the irrigation water into the tank; and the entire fertilizer amount in the tank is delivered to the irrigation area. Weighed quantity of soluble fertilizers as per schedule was dissolved in tank and then into lateral lines as per the treatment. Fertigation was done on weekly basis through drip irrigation.

\section{Flowering Pattern}

The number of male, intermediate flowers and hermaphrodite flowers were counted after thirty days of bahar treatment and their percentile was computed.

\section{Harvesting and Grading}

The pomegranate fruits were harvested in four pickings from April to May 2017. The marketable fruits harvested from each plant were graded as per the guidelines from Directorate of Marketing and Inspection 
(DMI), India and accordingly fruits were categorized in to three grades viz., $<250 \mathrm{~g}, 250-300 \mathrm{~g}$ and $>300 \mathrm{~g}$. The weight of the fruit harvested from pomegranate plant at each picking was measured and pooled weight was used to express fruit yield per plant in kilogram.

\section{Fruit quality parameter}

The five fruits picked randomly ( 1 from $>300 \mathrm{~g}, 3$ from $250-300 \mathrm{~g}$ and 1 from $<250 \mathrm{~g}$ ) in each replication were used to record the fruit parameters viz., average fruit weight, average fruit diameter (horizontal axis) and length (vertical axis) using vernier calipers, average peel weight including lamella and aril weight. The aril weight was divided by the peel weight to obtain aril to peel ratio and randomly chosen five aril's broadest length and width was measured using vernier calipers and average was computed.

\section{Juice quality parameter}

The $\mathrm{pH}$ of fresh pomegranate juice was estimated by using digital $\mathrm{pH}$ meter having a combined electrode as described by Jackson (1973). The total soluble solids (TSS) of the fresh juice were recorded using digital refractometer (Model HI 9680I) at $26.5^{\circ} \mathrm{C}$ and expressed in ${ }^{0}$ Brix. The total titrable acidity of juice samples were estimated by titrating known quantity of juice sample against $0.01 \mathrm{~N} \mathrm{NaOH}$ using phenolphthalein. The value was expressed in terms of percent titrable acidity equivalent to citric acid (AOAC 1984). Ascorbic acid content of fresh pomegranate juice was estimated titrimetrically using 2, 6- dicholrophenol indophenol dye as per the modified procedure of AOAC. Known quantity of juice was diluted to known volume with four per cent oxalic acid and an aliquot of five $\mathrm{ml}$ was titrated against 2, 6-dichlorophenol indophenols to express the result as mg of ascorbic acid per $100 \mathrm{ml}$ of fruit juice. The percentage of 2,2- diphenyl 1- picrylhydrazyl (DPPH) radical scavenging activity of pomegranate juice and fresh peel samples were used to determine their antioxidant activity as described by Eghdami \& Asli (2010). A known weight of fresh peel was crushed with $2 \mathrm{ml}$ of methanol and vortexed thoroughly for 10 minutes. The supernatant sample was then mixed $3.9 \mathrm{ml} \mathrm{of} 25 \mathrm{mg} \mathrm{L}^{-1}$ methanolic solution of DPPH, vortexed for 1 minute and kept for 30 minutes in darkness at $37^{\circ} \mathrm{C}$. A blank was prepared similarly with methanol. Then samples were read at spectrophotometer at $517 \mathrm{~nm}$ and calculated as following,

$$
\text { Antioxidant activity }(\%)=\frac{\text { A } 517 \mathrm{~nm} \text { of control }- \text { A } 517 \mathrm{~nm} \text { of sample }}{\text { A } 517 \mathrm{~nm} \text { of control }} \times 100
$$

The phenolic content in known weight of fresh peel and juice was extracted with $80 \%$ ethanol and treated with Folin Ciocalteau reagent and sodium carbonate. The intensity of color developed was read using spectrophotometer at $650 \mathrm{~nm}$. The total phenol content was calculated by referring to standard graph and expressed in mg per gram of fresh sample (Sadasivam \& Manickam 2005).

\section{Pomegranate juice and seed mineral content}

Pomegranate fruits were cut into four to six parts by stainless steel knife. Then the peel and arils were separated manually. Juice was extracted from arils by using manual juice extractor and immediately subjected to quality and nutrient analysis. The seeds separated during the extraction of juice were collected and washed with distilled water and oven dried at $65^{\circ} \mathrm{C}$. Later, powdered the samples using stainless steel mixer jar and preserved in paper cover and stored for the further analysis.

Table 1. Analytical methods followed for determination of mineral content in pomegranate juice and seeds.

\begin{tabular}{lll}
\hline Parameters & Methods & Reference \\
\hline Total Nitrogen & Kjeldhal Distillation method & \\
Total Phosphorus & Vanadomolybdate method & Piper (1966) \\
Total Potassium & Flame photometry & \\
Total Calcium & Versenate titration method & \\
Total Magnesium & Versenate titration method & \\
Total Sulfur & $\mathrm{BaCl}_{2}$ Turbidimetry & \\
\hline
\end{tabular}

The pomegranate juice was acid digested for determining its mineral composition except for nitrogen done by siphoning $25 \mathrm{ml}$ of the extracted juice and treated with di-acid $\left(\mathrm{HNO}_{3}: \mathrm{HClO}_{4^{-}}\right.$10:4). Further, it was digested on the sand bath and the sample was used to determine the mineral content in the juice sample by adopting the standard protocols as indicated in table $1.0 .5 \mathrm{~g}$ of oven dried pomegranate seeds were acid digested similar to juice as described to find its mineral content.

Nitrogen content in juice was estimated using $15 \mathrm{ml}$ of the extracted juice sample by digesting with conc. $\mathrm{H}_{2} \mathrm{SO}_{4}$ in presence of digestion mixture $\left(\mathrm{CuSO}_{4}: \mathrm{K}_{2} \mathrm{SO}_{4}: \mathrm{Se}\right.$ in 100:40:1). The digested sample was distilled 
under alkaline condition (by adding $40 \% \mathrm{NaOH}$ solution) and the distilled ammonia was trapped in $4 \%$ boric acid plus mixed indicator solution. The ammonia collected in boric acid was titrated against standard acid for estimation (Piper 1966). Similarly $0.5 \mathrm{~g}$ of oven-dried pomegranate seeds was used to find its nitrogen content by following the above-said protocol.

\section{RESULTS AND DISCUSSION}

\section{Effect of fertigation on pomegranate flowering}

Development of flowers after bahar treatment and the type of flowers are the key factors that govern fruit yield and quality in pomegranate cultivation. Pomegranate is characterized by having both bisexual (hermaphrodite) and functionally male flowers on the same tree, a condition referred to as andromonecy (Wetzstein et al. 2015). Some authors also signify an intermediate type flowers that exhibit weak pistil development (Wetzstein et al. 2015) that also have bisexual character. In the present investigation, the highest number of flowers was observed in schedule-2 $\left(\mathrm{T}_{5^{-}}-222.0\right.$ and $\left.\mathrm{T}_{3^{-}}-214.0\right)$ and $100 \%$ fertigation $\left(\mathrm{T}_{6^{-}}\right.$199.0) $^{-10}$ treatments as compared to schedule-1 $\left(\mathrm{T}_{2}-160.0\right.$ and $\left.\mathrm{T}_{4}-172.0\right)$ and $100 \%$ soil application $\left(\mathrm{T}_{1}-162.0\right)($ Table 2$)$. This could be attributed to the supply of $\mathrm{N}$ to pomegranate plants. Abundant nitrogen supply with ample opportunity for carbohydrate synthesis is known to produce vegetative growth and reduce flowering (Corbesier et al. 2002). Bernier et al. (1981) and Rideout et al. (1992) reported wider C:N endogenous ratio promotes flowering in plants while, narrow ratio stimulated vegetative growth. Amongst various treatments high leaf $\mathrm{N}$ content was observed in $100 \%$ soil application $\left(\mathrm{T}_{1^{-}}-2.09 \%\right)$ and schedule-1 $\left(\mathrm{T}_{2^{-}}-2.01 \%\right.$ and $\left.\mathrm{T}_{4^{-}} 1.98 \%\right)$ fertigation treatments (data not given). This might have reduced flowering by enhanced vegetative growth during bud differentiation (Corbesier et al. 2002). The hermaphrodite flowers that possess positive correlation with fruit yield (Shanmugasundaram \& Balakrishnamurthy 2013) were significantly higher in treatments that received lower basal application of $\mathrm{N}$ viz., $\mathrm{T}_{5}(123.0) \mathrm{T}_{4}$ (128.0) and $\mathrm{T}_{6}(107.0)$.

Table 2. Pomegranate flowering pattern as influenced by fertigation.

\begin{tabular}{lrrr}
\hline Treatments & $\begin{array}{r}\text { No. of male } \\
\text { flower }\end{array}$ & $\begin{array}{r}\text { No. of hermaphrodite } \\
\text { flower }\end{array}$ & $\begin{array}{r}\text { Total number of } \\
\text { flowers }\end{array}$ \\
\hline $\mathrm{T}_{1^{-}}-100 \% \mathrm{SA}$ & $78.0(48.1)$ & $84.0(51.9)$ & 162.0 \\
$\mathrm{~T}_{2}-50 \% \mathrm{SA}+50 \% \mathrm{~F}(\mathrm{~S} 1)$ & $78.0(48.8)$ & $82.0(51.2)$ & 160.0 \\
$\mathrm{~T}_{3}-50 \% \mathrm{SA}+50 \% \mathrm{~F}(\mathrm{~S} 2)$ & $92.0(43.1)$ & $122.0(56.9)$ & 214.0 \\
$\mathrm{~T}_{4}-25 \% \mathrm{SA}+75 \% \mathrm{~F}(\mathrm{~S} 1)$ & $83.0(48.3)$ & $89.0(51.7)$ & 172.0 \\
$\mathrm{~T}_{5}-25 \% \mathrm{SA}+75 \% \mathrm{~F}(\mathrm{~S} 2)$ & $94.0(42.4)$ & $128.0(57.6)$ & 222.0 \\
$\mathrm{~T}_{6}-100 \% \mathrm{~F}$ & $92.0(46.2)$ & $107.0(53.8)$ & 199.0 \\
\hline SEm & 3.21 & 8.72 & 6.3 \\
\hline
\end{tabular}

Note: Numbers in the parenthesis indicate the per cent number of flowers to the total number of flowers.

\section{Effect of fertigation on pomegranate fruit yield and yield parameters}

Number of Fruits: The optimum number of fruits determine fruit yield and quality in pomegranate and it is directly correlated with flowering pattern. The highest number of fruits were recorded in $\mathrm{T}_{5}(67.25)$ followed by $\mathrm{T}_{3}(54)$ and $\mathrm{T}_{6}(58.75)$ (Table 3 ). The hermaphrodite flowers has positive correlation with fruit bearing in pomegranate (NRCP 2011). Relatively lower number of hermaphrodite flowers in schedule-1 fertigation and $100 \%$ soil application $\left(\mathrm{T}_{1}\right)$ might have reduced fruit number in these treatments. The findings of Singh et al. (2006), Shanmugasundaram \& Balakrishnamurthy (2013) and Haneef et al. (2014) also confirm higher number of fruits with the fertigation treatment in pomegranate.

Table 3. Effect of fertigation on pomegranate fruit yield and yield parameters.

\begin{tabular}{lrrrrr}
\hline Treatments & $\begin{array}{r}\text { No. of fruits } \\
\text { per plant }\end{array}$ & $\begin{array}{r}\text { Fruit Weight } \\
(\mathbf{g})\end{array}$ & $\begin{array}{r}\text { Fruit Diameter } \\
(\mathbf{m m})\end{array}$ & $\begin{array}{r}\text { Fruit Length } \\
(\mathbf{m m})\end{array}$ & $\begin{array}{r}\text { Fruit Yield } \\
\left(\mathbf{k g ~ p l a n t}^{-1}\right)\end{array}$ \\
\hline $\mathrm{T}_{1^{-}}-100 \% \mathrm{SA}$ & 52.25 & 198.4 & 72.09 & 70.60 & 11.36 \\
$\mathrm{~T}_{2}-50 \% \mathrm{SA}+50 \% \mathrm{~F}(\mathrm{~S} 1)$ & 50.50 & 210.5 & 72.75 & 71.53 & 12.06 \\
$\mathrm{~T}_{3}-50 \% \mathrm{SA}+50 \% \mathrm{~F}$ (S2) & 59.00 & 247.6 & 73.98 & 74.74 & 14.98 \\
$\mathrm{~T}_{4^{-}}$25\% SA + 75\% F (S1) & 51.50 & 236.5 & 76.02 & 75.92 & 13.46 \\
$\mathrm{~T}_{5^{-}}$25\% SA + 75\% F (S2) & 67.25 & 270.3 & 78.78 & 80.03 & 18.49 \\
$\mathrm{~T}_{6}-100 \% \mathrm{~F}$ & 58.75 & 288.5 & 79.71 & 76.07 & 16.89 \\
\hline & 1.57 & 9.62 & 1.70 & 1.75 & 0.57 \\
\hline $\mathrm{SEm} \pm$ & 4.80 & 29.52 & 5.21 & 5.37 & 1.76 \\
\hline
\end{tabular}

Fruit weight and Size: The average fruit weight of pomegranate varied from $198.40 \mathrm{~g}$ to $288.50 \mathrm{~g}$ in different treatments (Table 3). The highest fruit weight $(288.50 \mathrm{~g})$ was observed in $100 \%$ fertigation $\left(\mathrm{T}_{6}\right)$ that was on 
par with $\mathrm{T}_{5}(75 \% \mathrm{~F}$ schedule-2- $270.30 \mathrm{~g})$ and the lowest fruit weight $(198.40 \mathrm{~g})$ was observed in $100 \%$ soil application $\left(\mathrm{T}_{1}\right)$. The maximum fruit diameter of $79.71 \mathrm{~mm}$ was found in $\mathrm{T}_{6}(100 \% \mathrm{~F})$ treatment, while fruit length was highest in $\mathrm{T}_{5}(75 \% \mathrm{~F}-80.03 \mathrm{~mm})$. The treatment receiving $100 \%$ soil application recorded lowest fruit diameter $(72.09 \mathrm{~mm})$ and length $(70.60 \mathrm{~mm})$. Continuous supply of primary nutrients through fertigation till fruit enlargement stage might have resulted in maintenance of high nutrient availability throughout the crop growth hence, promoting better fruit size and weight. The increase in fruit size and weight with increasing quntity of $\mathrm{N}, \mathrm{P}, \mathrm{K}$ fertilizers through fertigation was also reported by Shirgure et al. (2001), Mahalakshmi et al. (2001) and Thakur \& Singh (2004).

Fruit yield: The highest marketable fruit yield of $18.49 \mathrm{~kg} \mathrm{plant}^{-1}$ was recorded in $\mathrm{T}_{5}(25 \% \mathrm{SA}+75 \% \mathrm{~F}$ with schedule-2) that was on par with $\mathrm{T}_{6}\left(100 \% \mathrm{~F}-16.89 \mathrm{~kg}\right.$ plant $\left.{ }^{-1}\right)$ (Table 3). The treatment receiving $100 \%$ soil application of primary nutrients recorded the lowest fruit yield $11.36 \mathrm{~kg} \mathrm{plant}^{-1}$. Further, partial supplementation of major nutrients through fertigation enhanced the fruit yield recording $14.98 \mathrm{~kg} \mathrm{plant}^{-1}$, $13.46 \mathrm{~kg}$ plant $^{-1}$ and $12.06 \mathrm{~kg}$ plant $^{-1}$ in $\mathrm{T}_{3}, \mathrm{~T}_{4}$ and $\mathrm{T}_{2}$ respectively. This could be attributed to slower vegetative growth during bahar initiation followed by higher number of hermaphrodite flowers, higher number of fruits and fruit weight in these treatments. Keeping lower dose of basal application of major nutrients $\left(5: 15: 15 \% \mathrm{RD} \mathrm{N}: \mathrm{P}_{2} \mathrm{O}_{5}: \mathrm{K}_{2} \mathrm{O}\right)$ and applying relatively higher quantity $\left(75: 75: 75 \% \mathrm{RD} \mathrm{N}_{2} \mathrm{P}_{2} \mathrm{O}_{5}\right.$ : $\mathrm{K}_{2} \mathrm{O}$ ) during active growth stages with higher number of split application has resulted in high amount of nutrient availability at critical growth stages. These factors might have enhanced fruit yield in fertigation treatments compared to soil application. Enhanced fruit yield with fertigation was also observed by Shirgure et al. (2001), Mahalakshmi et al. (2001) and Thakur \& Singh (2004).

\section{Effect of fertigation on pomegranate fruit quality parameters}

Pomegranate fruit peel weight, aril weight, aril to peel ratio, aril length and aril breadth are the quality parameters that significantly influences its shelf life and consumer preference (Table 4). Application of primary nutrients $100 \%$ through fertigation $\left(\mathrm{T}_{6}\right)$ recorded significantly higher aril weight $(183.4 \mathrm{~g})$, peel weight $(98.30 \mathrm{~g})$ and aril to peel ratio (1.87) and found on par with $\mathrm{T}_{5}(169.43 \mathrm{~g}, 91.6 \mathrm{~g}$ and 1.84 respectively). Application of $50 \%$ RDF through schedule-2 fertigation recorded relatively higher quality parameters as compared to $75 \%$ RDF through schedule-1 fertigation. The $100 \%$ soil application recorded the lowest quality parameters as compared to all other treatments. A similar trend was observed with aril length and aril breadth where $\mathrm{T}_{6}$ recorded maximum values of 10.89 and $7.13 \mathrm{~mm}$ respectively that were on par with $\mathrm{T}_{5}(10.82 \mathrm{~mm}$ and 7.04 $\mathrm{mm})$ and $\mathrm{T}_{3}(10.74 \mathrm{~mm}$ and $6.93 \mathrm{~mm})$. The nutrient supply and its assimilation by crop are known to have significant influence on fruit quality parameters. Potassium is required for translocation of photosynthates from source (leaves) to sink (fruit) (Khayyat et al. 2012). Similarly, the optimum nitrogen is required for accumulation of protein and for fleshiness of fruit (Rao \& Subramanyam 2009). Optimum calcium supply is required for thickness of peel and to avoid cracking of fruits (Korkmaz \& Askin 2015). All these factors might have contributed to better quality parameters in treatments receiving higher quantity of primary nutrients through fertigation. Fruit maturation stage requires relatively higher K to improve fruit quality which might have fulfilled in fertigation treatments. Study of Singh et al. (1988) and Khayyat et al. (2012) also indicated improved fruit quality parameters with application of $\mathrm{K}$ during fruit maturity stage.

Table 4. Effect of fertigation on pomegranate fruit quality parameters.

\begin{tabular}{|c|c|c|c|c|c|}
\hline Treatments & $\begin{array}{r}\text { Peel Weight } \\
\text { (g/fruit) }\end{array}$ & $\begin{array}{r}\text { Arils Weight } \\
\text { (g/fruit) }\end{array}$ & $\begin{array}{r}\text { Aril/ } \\
\text { Peel }\end{array}$ & $\begin{array}{r}\text { Aril Length } \\
(\mathbf{m m})\end{array}$ & $\begin{array}{r}\text { Aril Breadth } \\
(\mathrm{mm})\end{array}$ \\
\hline $\mathrm{T}_{1}-100 \% \mathrm{SA}$ & 79.75 & 110.25 & 1.32 & 9.60 & 6.14 \\
\hline $\mathrm{T}_{2}-50 \% \mathrm{SA}+50 \% \mathrm{~F}(\mathrm{~S} 1)$ & 83.25 & 122.30 & 1.41 & 10.37 & 6.65 \\
\hline $\mathrm{T}_{3}-50 \% \mathrm{SA}+50 \% \mathrm{~F}(\mathrm{~S} 2)$ & 86.00 & 153.23 & 1.76 & 10.74 & 6.93 \\
\hline $\mathrm{T}_{4}-25 \% \mathrm{SA}+75 \% \mathrm{~F}(\mathrm{~S} 1)$ & 86.25 & 144.45 & 1.68 & 10.44 & 6.86 \\
\hline $\mathrm{T}_{5}-25 \% \mathrm{SA}+75 \% \mathrm{~F}(\mathrm{~S} 2)$ & 91.60 & 169.43 & 1.84 & 10.82 & 7.04 \\
\hline $\mathrm{T}_{6}-100 \% \mathrm{~F}$ & 98.30 & 183.40 & 1.87 & 10.89 & 7.13 \\
\hline SEm & 3.19 & 8.57 & 0.10 & 0.23 & 0.18 \\
\hline $\mathrm{CD}$ at $5 \%$ & 9.79 & 26.30 & 0.30 & 0.71 & 0.54 \\
\hline
\end{tabular}

Effect of fertigation on pomegranate fruit juice quality parameters

The pomegranate juice $\mathrm{pH}$ and TSS did not record significant variation due to different treatments while, titrable acidity and ascorbic acid content varied significantly among different treatments (Table 5). The juice $\mathrm{pH}$ ranged from $3.46-3.65$ and TSS from $15.05-15.85^{\circ} \mathrm{B}$. The titrable acidity and ascorbic acid content was highest in $\mathrm{T}_{6}$ recording $0.91 \%$ and $23.93 \mathrm{mg} / 100 \mathrm{ml}$ respectively followed by $\mathrm{T}_{5}(0.85 \%$ and $21.34 \mathrm{mg} / 100 \mathrm{ml}$ 
respectively). The variation in these parameters could be due to higher $\mathrm{K}$ and $\mathrm{N}$ content in these treatments. Khayyat et al. (2012) reported increased titrable acidity and ascorbic acid content in pomegranate fruit juice with the application of $250 \mathrm{mg} \mathrm{L}^{-1}$ plant $^{-1}$ of $\mathrm{K}$ during fruit enlargement stage owing to its role in accumulation of higher photosynthates (carbohydrates) in fruits. Further, higher levels of nitrogen stimulate synthesis and catalytic activity of several enzymes and co-enzymes which are instrumental in ascorbic acid synthesis (Boora \& Singh 2000, Sheikh \& Manjula 2012).

Table 5. Effect of fertigation on pomegranate fruit juice quality parameters.

\begin{tabular}{|c|c|c|c|c|}
\hline Treatments & pH & TSS $\left({ }^{0} \mathrm{~B}\right)$ & $\begin{array}{r}\text { Titrable } \\
\text { acidity }(\%)\end{array}$ & $\begin{array}{r}\text { Ascorbic acid } \\
(\mathrm{mg} / 100 \mathrm{ml})\end{array}$ \\
\hline $\mathrm{T}_{1}-100 \% \mathrm{SA}$ & 3.65 & 15.33 & 0.72 & 19.13 \\
\hline $\mathrm{T}_{2^{-}} 50 \% \mathrm{SA}+50 \% \mathrm{~F}(\mathrm{~S} 1)$ & 3.61 & 15.70 & 0.76 & 19.29 \\
\hline $\mathrm{T}_{3^{-}} 50 \% \mathrm{SA}+50 \% \mathrm{~F}(\mathrm{~S} 2)$ & 3.60 & 15.05 & 0.82 & 20.82 \\
\hline $\mathrm{T}_{4}-25 \% \mathrm{SA}+75 \% \mathrm{~F}(\mathrm{~S} 1)$ & 3.59 & 15.58 & 0.80 & 20.30 \\
\hline $\mathrm{T}_{5}-25 \% \mathrm{SA}+75 \% \mathrm{~F}(\mathrm{~S} 2)$ & 3.53 & 15.85 & 0.85 & 21.34 \\
\hline $\mathrm{T}_{6}-100 \% \mathrm{~F}$ & 3.46 & 15.60 & 0.91 & 23.93 \\
\hline SEm \pm & NS & NS & 0.03 & 0.83 \\
\hline $\mathrm{CD}$ at $5 \%$ & NS & NS & 0.08 & 2.56 \\
\hline
\end{tabular}

The pomegranate juice recorded highest phenolic content and antioxidant activity in $100 \%$ fertigation treatment ( $0.66 \mathrm{mg} \mathrm{g}^{-1}$ and $52.55 \%$ respectively) followed by $\mathrm{T}_{5}\left(0.63 \mathrm{mg} \mathrm{g}^{-1}\right.$ and $50.05 \%$ respectively) (Table 6). A similar trend was observed in the fruit peel. The exact reason for higher accumulation is obscure. However, some literature reveals a positive correlation between $\mathrm{K}$ and phenols, $\mathrm{K}$ and antioxidant activity (Dani et al. 2007, Tamuly et al. 2013).

Table 6. Effect of fertigation on phenolic content and antioxidant activity of pomegranate fruit.

\begin{tabular}{|c|c|c|c|c|}
\hline \multirow[t]{2}{*}{ Treatments } & \multicolumn{2}{|c|}{$\begin{array}{c}\text { Phenolic content } \\
\left(\mathrm{mg} \mathrm{g}^{-1}\right)\end{array}$} & \multicolumn{2}{|c|}{$\begin{array}{c}\text { Antioxidant activity } \\
(\%)\end{array}$} \\
\hline & Juice & Peel & Juice & Peel \\
\hline $\mathrm{T}_{1}-100 \% \mathrm{SA}$ & 0.53 & 0.84 & 42.75 & 68.87 \\
\hline $\mathrm{T}_{2}-50 \% \mathrm{SA}+50 \% \mathrm{~F}(\mathrm{~S} 1)$ & 0.57 & 0.87 & 44.14 & 69.20 \\
\hline $\mathrm{T}_{3}-50 \% \mathrm{SA}+50 \% \mathrm{~F}(\mathrm{~S} 2)$ & 0.61 & 0.93 & 48.52 & 70.40 \\
\hline $\mathrm{T}_{4}-25 \% \mathrm{SA}+75 \% \mathrm{~F}(\mathrm{~S} 1)$ & 0.62 & 0.91 & 46.77 & 71.94 \\
\hline $\mathrm{T}_{5}-25 \% \mathrm{SA}+75 \% \mathrm{~F}(\mathrm{~S} 2)$ & 0.63 & 0.93 & 50.05 & 77.41 \\
\hline $\mathrm{T}_{6^{-}}-100 \% \mathrm{~F}$ & 0.66 & 0.99 & 52.55 & 79.43 \\
\hline SEm \pm & 0.02 & 0.02 & 2.00 & 2.24 \\
\hline $\mathrm{CD}$ at $5 \%$ & 0.06 & 0.07 & 6.14 & 6.89 \\
\hline
\end{tabular}

Effect of fertigation on pomegranate juice and seed mineral content

Table 7. Effect of fertigation on pomegranate juice mineral content.

\begin{tabular}{|c|c|c|c|c|c|c|}
\hline \multirow[b]{2}{*}{ Treatments } & \multicolumn{2}{|c|}{$\mathbf{N}$} & \multicolumn{2}{|c|}{$\mathbf{P}$} & \multicolumn{2}{|c|}{$\mathbf{K}$} \\
\hline & $\begin{array}{c}\text { Juice } \\
\left(g^{-1} \mathbf{L}^{-1}\right)\end{array}$ & $\begin{array}{r}\text { Seed } \\
(\%)\end{array}$ & $\begin{array}{r}\text { Juice } \\
\left(\mathrm{g} \mathrm{L}^{-1}\right)\end{array}$ & $\begin{array}{r}\text { Seed } \\
(\%)\end{array}$ & $\begin{array}{c}\text { Juice } \\
\left(g^{-1} \mathbf{L}^{-1}\right)\end{array}$ & $\begin{array}{r}\text { Seed } \\
(\%)\end{array}$ \\
\hline $\mathrm{T}_{1}-100 \% \mathrm{SA}$ & 4.34 & 1.51 & 1.95 & 0.33 & 7.68 & 0.78 \\
\hline $\mathrm{T}_{2^{-}}-50 \% \mathrm{SA}+50 \% \mathrm{~F}(\mathrm{~S} 1)$ & 4.87 & 1.53 & 2.32 & 0.43 & 7.86 & 0.81 \\
\hline $\mathrm{T}_{3}-50 \% \mathrm{SA}+50 \% \mathrm{~F}(\mathrm{~S} 2)$ & 5.00 & 1.59 & 2.44 & 0.44 & 8.13 & 0.91 \\
\hline $\mathrm{T}_{4}-25 \% \mathrm{SA}+75 \% \mathrm{~F}(\mathrm{~S} 1)$ & 5.20 & 1.62 & 2.59 & 0.43 & 7.93 & 0.86 \\
\hline $\mathrm{T}_{5^{-}}-25 \% \mathrm{SA}+75 \% \mathrm{~F}(\mathrm{~S} 2)$ & 5.40 & 1.73 & 2.48 & 0.47 & 8.85 & 1.06 \\
\hline \multirow[t]{5}{*}{$\mathrm{T}_{6}-100 \% \mathrm{~F}$} & 5.87 & 1.77 & 2.78 & 0.49 & 9.31 & 1.04 \\
\hline & 0.25 & 0.04 & 0.14 & 0.02 & 0.34 & 0.05 \\
\hline & 0.76 & 0.13 & 0.43 & 0.08 & 1.03 & 0.14 \\
\hline & \multicolumn{2}{|c|}{$\mathbf{C a}$} & \multicolumn{2}{|c|}{$\mathrm{Mg}$} & \multicolumn{2}{|c|}{$\mathbf{S}$} \\
\hline & $\begin{array}{r}\text { Juice } \\
\left(\mathrm{g} \mathrm{L}^{-1}\right)\end{array}$ & $\begin{array}{r}\text { Seed } \\
(\%)\end{array}$ & $\begin{array}{r}\text { Juice } \\
\left(\mathrm{g} \mathrm{L} \mathrm{L}^{-1}\right)\end{array}$ & $\begin{array}{r}\text { Seed } \\
(\%)\end{array}$ & $\begin{array}{c}\text { Juice } \\
\left(\mathrm{g} \mathrm{L}^{-1}\right)\end{array}$ & $\begin{array}{r}\text { Seed } \\
(\%)\end{array}$ \\
\hline $\mathrm{T}_{1}-100 \% \mathrm{SA}$ & 0.66 & 0.41 & 0.42 & 0.30 & 1.75 & 0.10 \\
\hline $\mathrm{T}_{2^{-}}-50 \% \mathrm{SA}+50 \% \mathrm{~F}(\mathrm{~S} 1)$ & 0.69 & 0.39 & 0.45 & 0.32 & 1.81 & 0.11 \\
\hline $\mathrm{T}_{3}-50 \% \mathrm{SA}+50 \% \mathrm{~F}(\mathrm{~S} 2)$ & 0.73 & 0.48 & 0.44 & 0.36 & 1.91 & 0.14 \\
\hline $\mathrm{T}_{4}-25 \% \mathrm{SA}+75 \% \mathrm{~F}(\mathrm{~S} 1)$ & 0.68 & 0.44 & 0.49 & 0.34 & 1.83 & 0.11 \\
\hline $\mathrm{T}_{5}-25 \% \mathrm{SA}+75 \% \mathrm{~F}(\mathrm{~S} 2)$ & 0.84 & 0.50 & 0.50 & 0.40 & 2.12 & 0.16 \\
\hline $\mathrm{T}_{6}-100 \% \mathrm{~F}$ & 0.86 & 0.51 & 0.51 & 0.42 & 2.34 & 0.18 \\
\hline SEm \pm & NS & NS & NS & 0.02 & 0.08 & 0.008 \\
\hline $\mathrm{CD}$ at $5 \%$ & NS & NS & NS & 0.06 & 0.26 & 0.023 \\
\hline
\end{tabular}


The mineral content in pomegranate juice showed significant variation due to various treatments with respect to $\mathrm{N}, \mathrm{P}, \mathrm{K}$ and $\mathrm{S}$ while, the treatment effect was insignificant on $\mathrm{Ca}$ and $\mathrm{Mg}$ (Table 7). In general the concentration of nutrient content in juice were in the order of $\mathrm{K}>\mathrm{N}>\mathrm{P}>\mathrm{S}>\mathrm{Ca}>\mathrm{Mg}$ (Raghupathi \& Bhargava 1996). Amongst the major nutrients, highest $\mathrm{K}$ was noticed in $\mathrm{T}_{6}\left(100 \% \mathrm{~F}-9.31 \mathrm{~g} \mathrm{~L}^{-1}\right)$ followed by $\mathrm{T}_{5}(25 \% \mathrm{SA}+$ $75 \% \mathrm{~F}$ with schedule-2- $\left.8.85 \mathrm{~g} \mathrm{~L}^{-1}\right)$. Similarly highest $\mathrm{P}$ and $\mathrm{N}$ content was observed in $\mathrm{T}_{6}\left(2.78 \mathrm{~g} \mathrm{~L}^{-1}\right.$ and $5.87 \mathrm{~g}$ $\mathrm{L}^{-1}$ respectively) followed by $\mathrm{T}_{5}\left(2.48\right.$ and $\left.5.40 \mathrm{~g} \mathrm{~L}^{-1}\right)$.

The mineral content in seeds varied significantly due to the effect of various treatments except for $\mathrm{Ca}$. The content of these nutrients in seeds followed the order $\mathrm{N}>\mathrm{K}>\mathrm{P}>\mathrm{Ca}>\mathrm{S}>\mathrm{Mg}$ (Raghupathi \& Bhargava 1996). The concentration of $\mathrm{N}$ was maximum compared to other nutrients and highest was recorded in $100 \%$ fertigation $\left(\mathrm{T}_{6}-1.77 \%\right)$. The $\mathrm{P}$ content was found highest in $\mathrm{T}_{6}(0.49 \%)$ followed by $\mathrm{T}_{5}(0.47)$ but, the $\mathrm{K}$ content was higher in $\mathrm{T}_{5}(1.06 \%)$ followed by $\mathrm{T}_{6}(1.04 \%)$. This could be attributed to the higher rate and number of split application of primary nutrients during active growth stage resulting in higher accumulation in leaves and further translocation to fruits (Rao \& Subramanyam 2009). The Mg and S content also high in 100\% fertigation ( $\mathrm{T}_{6^{-}} 0.42$ and $0.18 \%$ respectively) followed by $\mathrm{T}_{5}(0.40$ and $0.16 \%$ respectively).

\section{CONCLUSION}

The present investigation revealed that T5 treatment that includes application of primary nutrients $25 \%$ through soil application and $75 \%$ through fertigation schedule-2 was most effective in obtaining higher pomegranate fruit yield. However, the pomegranate fruit quality was superior with $100 \%$ fertigation (T6) of primary nutrients. The present study emphasizes need for applying relatively higher amount of primary nutrients during active growth stage by maintaining optimal supply at basal and rest period for enhancing pomegranate fruit productivity. Fertigation is a better option for obtaining quality fruit that assures higher number of split application of nutrients throughout active growth period.

\section{ACKNOWLEDGEMENTS}

We are thankful to Regional Horticulture Research and Extension Centre, Bagalkot and Netafim irrigation solutions and services for their support in conducting field experiments.

\section{REFERENCES}

Agarwal N, Sharma HG, Dixit A, Dubey A \& Agrawal S (2004) Effect of fertigation through water soluble fertilizers on growth, yield and quality of pomegranate. Journal of Agricultural Sciences 9: 13-18.

AOAC (1984) Official methods of analysis, $14^{\text {th }}$ edition. Association of Official Analytical Chemists Washington DC USA.

Bernier G, Kinet JM \& Sachs RM (1981) The Physiology of Flowering 1. CRC Press Boca Raton.

Boora R \& Singh D (2000) Effect of NPK on growth yield and quality of sapota cv. Cricket ball Haryana Journal of Horticulture Science 29(3): 188-189.

Corbesier L, Bernier G \& Perilleux C (2002) C: N ratio increases in the phloem sap during floral transition of the long-day plants Sinapis alba and Arabidopsis thaliana. Plant cell Physiology 43(6): 684-688.

Dani C, Oliboni LS, Vanderlinde R \& Bonatto (2007) Phenolic content and antioxidant activities of white and purple juices manufactured originally or conventionally- produced grapes. Food Chemistry Toxicology 45: 2574-2580.

Dhankar MK, Kaushik RA, Sarolia D \& Bana ML (2010) Effect of fertigation using low cost drip irrigation system on physic-chemical characteristics in pomegranate cv. Bhagwa. Indian Journal of Horticulture 67: 432-435.

Eghdami A \& Asli DE (2010) Determination of antioxidant capacity of pomegranate juice by using 2,2Diphenyl-1-picrylhydrazyl. Journal of Organic Chemistry 1: 30-33.

Firake NN \& Deolankar KP (2000) Response of pomegranate to soluble fertilizer through drip. Journal of Maharashtra agricultural university 25: 196-197.

Firake NN \& Kumbhar DB (2002) Effect of different levels of N, P and K fertigation on yield and quality of pomegranate. Journal of Maharashtra Agricultural Universities 27(2): 146-148.

Gosh GK, Mohan KS \& Sarkar AK (1996) Characterization of soil-fertilizer P reaction products and their evaluation as sources of P for gram (Cicer arietinum L.). Nutrient Cycling in Agrosystems 46(1): 71-79.

Haneef M, Kaushik RA, Sarolia DK, Mordia A \& Dhakar M (2014) Irrigation scheduling and fertigation in pomegranate cv. Bhagwa under high density planting system. Indian Journal of Horticulture 71(1): 45-48.

Idate GM, Chaudhari SM \& More TA (2001) Fertigation in pomegranate (Punica granatum L.) South Indian 
Horticulture 49: 69-70.

Jackson ML (1973) Soil Chemical Analysis. Prentice Hall of India Pvt. Ltd., New Delhi.

Jhakar M (2010) Effect of fertigation on growth of newly planted pomegranate under high density planting system and related hydraulic parameters. (M. Sc. Thesis). Rajasthan College of Agriculture, MPUAT, Udaipur (India).

Kafkafi U \& Tarchitzky J (2011) Fertigation: A tool for efficient fertilizer and water management. International Fertilizer industry Association, Paris.

Khayyat M, Tehranifar A, Zaree M, Karimian Z, Aminifard MH, Vazifeshenas MR, Amini S, Noori Y \& Shakeri M (2012) Effects of potassium Nitrate spraying on fruit characteristics of malasyazdi pomegranate. Journal of Plant Nutrition 35: 1387-1393.

Korkmaz N \& Askin MA (2015) Effects of calcium and boron foliar application on pomegranate (Punica granatum L.) fruit quality, yield and seasonal changes of leaf mineral nutrition. In: III International Symposium on Pomegranate and Minor Mediterranean Fruits, pp. 413-422.

Larue JH (1980) Growing pomegranates in California. Univ. The University of California Division of Agriculture and Natural Resources, Leaflet, 2459.

Li DG, Xu XC \& Zhang YL (2002) Fertigation and fertilizer. Journal of Zhengzhou University Technology 1: 21-24.

Mahalakshmi M, Kumar N, Jeyakumar P \& Soorrianathasundaram K (2001) Fertigation studies in banana under normal system of planting. South Indian Horticulture 49: 80-85.

NRCP (2011) Pomegranate growing manual, National Research Centre on Pomegranate. Solapur

Piper CS (1966) Soil and Plant Analysis. Han's Publication, Bombay

Prasad RN, Banker GJ \& Vashishtha BB (2003) Effect of drip irrigation on growth, yield and quality of pomegranate in arid region. The Indian Journal of Horticulture 60: 140-142.

Prasanna KB \& Dhander DG (1999) Response of pomegranate to NPK fertilization. Indian Journal of Horticulture 53: 114-117.

Raghupathi HB \& Bhargava BS (1996) Concentration of nutrients in different parts of pomegranate (Punica granatum L.) fruits. Karnataka Journal of Agricultural Sciences 9(4): 591-594.

Rao KD \& Subramanyam K (2009) Effect of nitrogen fertigation on growth and yield of pomegranate var. Mridula under low rainfall zone. Agriculture Science Digest 29(2): 1-3.

Rideout JW, Raper CD \& Miner GS (1992) Changes in ratio of soluble sugars and free amino nitrogen in the apical meristem during floral transition of tobacco. International Journal of Plant Sciences 153: 78-88.

Sadasivam MS \& Manickam A (2005) Biochemical methods, $2^{\text {nd }}$ edition. Newage International Publishers.

Shanmugasundaram T \& Balakrishnamurthy G (2013) Effect of fertigation on flowering and yield of tissue culture pomegranate (Punica granatum L.) cv. Mirdula grown under ultra high density planting (UHDP). The Asian Journal of Horticulture 8(2): 601-604.

Sheikh MK \& Manjula N (2012) Effect of chemical on control of fruit cracking in pomegranate (Punica granatum L.) var. Ganesh. In: $2^{\text {nd }}$ international Symposium on Pomegranate, pp. 133-135.

Shirgure PS, Srivastava \& Singh S (2001) Fertigation and drip irrigation in Nagpur mandarin (Citrus reticulate). South Indian Horticulture 49: 95-97.

Singh P, Singh AK \& Sahu K (2006) Irrigation and fertigation of pomegranate cv. Ganesh in chattishgarh. Indian Journal of Horticulture 63: 141-151.

Singh RR, Singh HK \& Chauhan KS (1988) Effect of N, P and K on physico-chemical composition of pomegranate fruits cv. Local selection. Progressive Horticulture 20: 77-79.

Still DW (2006) Pomegranates: A botanical perspective CRC Press, Boca Raton.

Sulochanamma BN, Reddy T \& Reddy R (2005) Effect of basin and drip irrigation on growth, yield and water use efficiency in pomegranate cv. Ganesh. In: VII International Symposium on Temperate Zone Fruits in the Tropics and Subtropics - Part Two, pp. 277-27.

Tamuly C, Saikia B, Hazarika M, Bora J, Bordoloi MJ \& Sahu OP (2013) Correlation Between Phenolic, Flavonoid, and Mineral Contents With Antioxidant Activity of Underutilized Vegetables. International Journal of Vegetable Science 19: 34-44.

Thakur SK \& Singh P (2004) Studies on fertigation of Mango cv. Amrapali. Annals of Agricultural Research 25 (3): 415-417.

Wetzstein HY, Porter JA \& Ravid N (2015) Reproductive biology of pomegranate from flowering to fruit development. In: III International Symposium on Pomegranate and Minor Mediterranean Fruits, pp. 121-125. 